\title{
The ascidian pump: properties and energy cost
}

\author{
Hans Ulrik Riisgård
}

Institute of Biology, University of Odense, DK-5230 Odense M, Denmark

\begin{abstract}
The ciliary pump for mucous-net filter feeding was studied in the ascidian Styela clava. The relationship between back pressure, $\Delta \mathrm{H}_{12}$, and pumping rate, $\mathrm{V}$, was experimentally determined, and could be represented as the linear function: $\Delta \mathrm{H}_{12}=a-b \mathrm{~V}$, where $a=\Delta \mathrm{H}_{12}$ is the maximum pressure rise (about $1.2 \mathrm{~mm} \mathrm{H} \mathrm{H}_{2} \mathrm{O}$ ) and $b=\Delta \mathrm{H}_{12}^{0} / \mathrm{V}^{0}$ is the slope, $\mathrm{V}^{0}$ being the pumping rate at zero back pressure. The normal operating point of the ascidian pump, $O_{p}$, was defined as the system resistance at zero back pressure: $\mathrm{O}_{\mathrm{p}}=\Delta \mathrm{H}_{\mathrm{s}}=\Delta \mathrm{H}_{\mathrm{m}}$ (pressure drop across mucous net) $+\Delta \mathrm{H}_{\mathrm{k}}$ (kinetic energy loss) $+\Delta \mathrm{H}_{\mathrm{f}}$ (frictional resistance). In the unrestricted and optimally working ascidian $\mathrm{O}_{\mathrm{p}}$ was found to be about $0.3 \mathrm{~mm} \mathrm{H}_{2} \mathrm{O}$. The pump characteristic (i.e. the relation between pump pressure, $\Delta \mathrm{H}_{\mathrm{p}}$ and pumping rate, $V$ ) was determined from the back pressure-pumping rate characteristic and $\mathrm{O}_{\mathrm{p}}$ as: $\Delta \mathrm{H}_{\mathrm{p}}=$ $\Delta H_{p}^{0}-C_{p} V$, where $\Delta H_{p}^{0}=H_{12}^{0}$ and $C_{p}=\left(\Delta H_{12}^{0}-O_{p}\right) / V^{0}$. The pumping rate-pumping power characteristic was a parabola. The work done by the pump was compared to the total metabolic energy expenditure expressed as the rate of oxygen consumption, and constituted about 0.1 to $0.2 \%$ of the metabolic rate. The ascidian ciliary pharyngeal pump operates at a low pressure and is a low energy pump compared to the ciliary bivalve gill pump.
\end{abstract}

\section{INTRODUCTION}

Like other tunicates, ascidians are suspension feeders that filter food particles, mainly phytoplankton, from the surrounding water. Ascidians pump water through the pharynx which is perforated with small slits, the stigmata. Ciliary tracts on either side of the stigmata create a water current which runs through the inhalant siphon into the pharyngeal chamber and through the stigmata into the atrium from which the water leaves the ascidian as a jet through the exhalant siphon. When the water is pumped across the pharynx wall, suspended particles are trapped on a mucous net continuously produced by the endostyle (Holley 1986). Cilia on the papillae or longitudinal pharyngeal bars transport the endless mucous net with the retained food particles to the dorsal lamina where it is rolled into a cord which is passed posteriorly into the esophagus as an unbroken string (MacGinitie 1939, Millar 1971, Fiala-Médioni 1978). Thus, the amount of food available to ascidians is determined by the efficiency with which the particles are retained by the mucous net and by the amount of water pumped through the pharynx as well as the concentration of food particles present. Particles down to $2-3 \mu \mathrm{m}$ are completely retained (Randløv \& Riisgård 1979), and electron microscopic studies of the mucous net have revealed that in the fixed state it is composed of 10 to $40 \mathrm{~nm}$ thick fibers arranged in rectangular meshes that vary between 0.2 and $0.5 \mu \mathrm{m}$ in width and between 0.5 and $2.2 \mu \mathrm{m}$ in length (Flood \& Fiala-Médioni 1981). There have been few attempts to study the ascidian pump and the energy expenditure of pumping large amounts of water through a mucous net which efficiently retains particles down to a few microns.

The aim of the present work was to study the ascidian ciliary pump, and to compare it to the ciliary gill pump of suspension feeding bivalves which has recently been analysed (Jørgensen et al. 1986, 1988, Jørgensen \& Riisgård 1988).

\section{MATERIALS AND METHODS}

Experiments were conducted in October and November 1987 at the Environmental System Laboratory, Woods Hole Oceanographic Institution, Woods Hole, Massachusetts, USA.

Ascidians Styela clava were collected in the outdoor aquaculture tank system and kept in the laboratory (30 to $32 \% \mathrm{~S} ;$ ca $15^{\circ} \mathrm{C}$ ) until used in experiments ( 3 to $45 \mathrm{~d}$ ). Direct measurements of pumping rates at various hydrostatic pressures imposed between the inhalant siphon and the exhalant siphon in 10 to $12 \mathrm{~cm}$ long 
ascidians were made using a modified version of the technique described by Famme et al. (1986) and Jørgensen et al. (1986) for direct measurement of pumping rates in Mytilus edulis. A 51 aquarium was divided into 2 chambers $\left(C_{1}\right.$ and $\left.C_{2}\right)$ by a latex rubber membrane (cut out of a condom) in which a circular hole had been punched. The exit siphon of the ascidian was inserted into the hole so that the membrane separated the inhalant water from the exhalant water (Fig. 1). A shunt connected the 2 chambers when open. The water level in the exhalant chamber $\left(C_{2}\right)$ was monitored with a laser beam striking a mirror that was fixed on a tethered floating ping-pong ball. The mirror reflected the laser beam onto a scale about $6 \mathrm{~m}$ from the mirror. When the ascidian pumped water from $C_{1}$ to $C_{2}$ with the shunt closed the water level could be kept at different back pressures by means of a peristaltic pump that pumped water from $\mathrm{C}_{2}$ to $\mathrm{C}_{1}$. The pumping rate of the calibrated peristaltic pump was identical to the pumping rate of the ascidian. A $1 \mathrm{~cm}$ beam movement on the scale was equivalent to a $0.059 \mathrm{~mm} \mathrm{H}_{2} \mathrm{O}$ change in back pressure.

Transfer of Styela clava from the holding tank to the experimental set-up disturbed the ascidian, but within $1 \mathrm{~h}$ it was usually in a normal state with extended and wide open siphons. In several cases, however, no or only a very low pumping activity was recorded. An increase in pumping rate as well as in maximal pressure rise (from about 0.4 to $1.2 \mathrm{~mm} \mathrm{H}_{2} \mathrm{O}$ ) was sometimes noticed after addition of algal cells to the water. Addition of algal cells (ca $10^{4}$ Isochrysis galbana cells $\mathrm{ml}^{-1}$ ) was therefore adapted as a standard procedure when measuring back pressure-flow characteristics and oxygen uptake. The back pressure characteristic was only measured if the ascidian was judged to be fully open and undisturbed. A total number of 11 individuals were studied. The only selection criteria was that the size and shape of the exhalant siphon of the fully open ascidian fitted into the hole in the membrane so that there were no shunts between the 2 chambers. All pumping rates were measured at $15^{\circ} \mathrm{C}$.

The oxygen consumption of Styela clava was measured by placing a specimen in a $500 \mathrm{ml}$ glass bottle filled with seawater and closed with a rubber stopper through which water samples for measurement of oxygen concentration with an oxygen electrode could be taken by means of a syringe. The pumping activity of the specimen ensured mixing of the water in the respiration chamber. The measurements were made at $15^{\circ} \mathrm{C}$ and at oxygen saturations between 60 and $90 \%$. The following conversion factor was used: $1 \mathrm{ml} \mathrm{O}_{2} \mathrm{~h}^{-1}=$ $5333 \mu \mathrm{W}\left(1 \mathrm{ml} \mathrm{O} 2=1.92 \times 10^{8}\right.$ ergs $)$.

After the experiments specimens were divided into test (tunica) and soft tissue for determination of total and soft tissue dry weights.

\section{RESULTS}

Fig. 2 shows 2 typical experiments with Styela clava in which the relation between imposed back pressure, $\Delta \mathrm{H}_{12}$, and pumping rate, $\mathrm{V}$, was determined. The relation conformed to the linear function

$$
\Delta \mathrm{H}_{12}=a-b \mathrm{~V}
$$

where $a=\Delta H_{12}^{0}$ is the intersection of the ordinate (at zero pumping rate); $b=\Delta H_{12}^{0} / V^{0}$ is the slope of the regression line, $V^{0}$ being the intersection of the $a b$ scissa (at zero back pressure). The results from 11 series of measurements with different individuals are shown

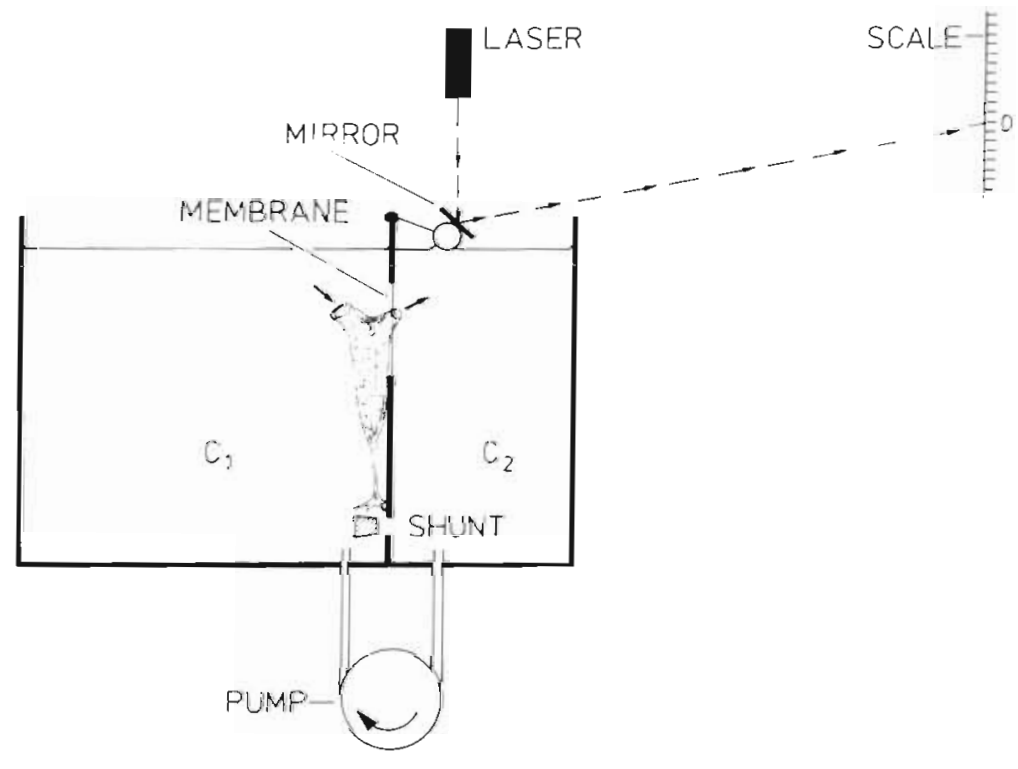

Fig. 1. Diagram of set-up for direct measurement of pumping rates in Styela clava 


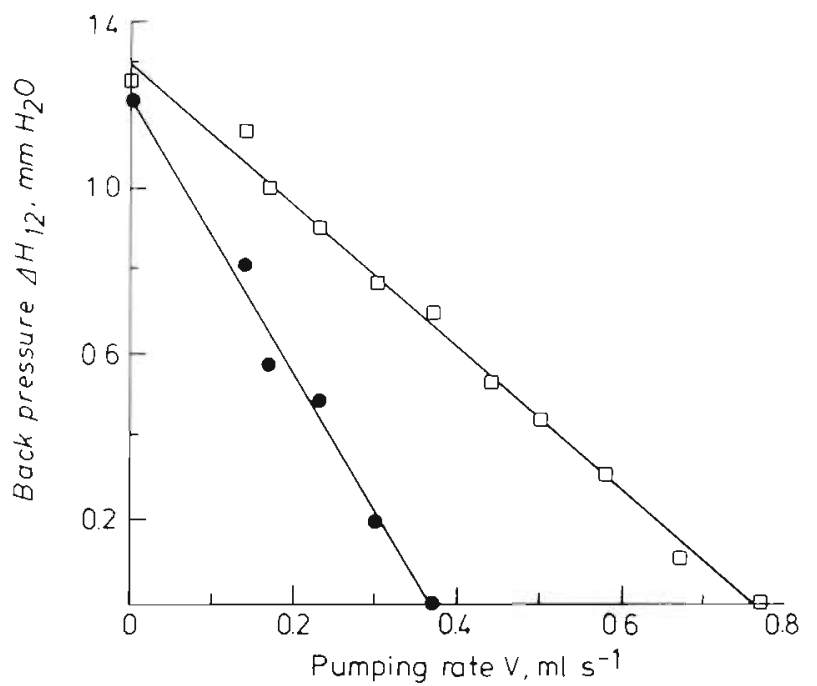

Fig. 2. Styela clava. Back pressure-pumping rate characteristic in 2 individuals ( $\square: \# 12, \#$ : 5 ; see Table 1). Regression lines are shown

in Table 1. The maximum pressure rise which could be delivered by the ascidian pump (i.e. $\Delta \mathrm{H}_{12}^{0}$ ) was consistently ca $1.2 \mathrm{~mm} \mathrm{H}_{2} \mathrm{O}$ and was independent of $\mathrm{V}^{0}$, which varied from individual to individual.

A water-pumping ascidian must generate a certain pressure to overcome the resistance to water flow. Pressure losses along the flow path in the ascidian are caused by frictional resistance in the system through which water is flowing and by loss of kinetic energy as water enters and leaves the siphons. At steady state, the operating pressure of the ascidian pump, $\Delta \mathrm{H}_{\mathrm{p}}$, is equal to the system resistance, $\Delta \mathrm{H}_{\mathrm{s}}$, which can be resolved into several components:

$$
\Delta \mathrm{H}_{\mathrm{s}}=\Delta \mathrm{H}_{\mathrm{m}}+\Delta \mathrm{H}_{\mathrm{k}}+\Delta \mathrm{H}_{\mathrm{f}}+\Delta \mathrm{H}_{12}
$$

where $\Delta \mathrm{H}_{\mathrm{m}}=$ pressure drop across the mucous net; $\Delta \mathrm{H}_{\mathrm{k}}=$ sum of the kinetic energy loss as water enters the inhalant and leaves the exhalant siphon; $\Delta \mathrm{H}_{\mathrm{f}}=$ frictional resistance in the canal system of the pump; $\Delta H_{12}=$ back pressure.

To determine the normal operating point (i.e. the pump head at zero back pressure) of the ascidian pharyngeal pump, Styela \# 12 was chosen as an example. The area of the pharynx wall was found from the contour of the optimally pumping ascidian to be ca $25 \mathrm{~cm}^{2}$. As $V^{0}$ was $0.76 \mathrm{ml} \mathrm{s}^{-1}$ (Table 1) this provides a flow velocity, $\bar{u}$, through the mucous filter of $0.30 \mathrm{~mm}$ $\mathrm{s}^{-1}$. The pressure drop, $\Delta \mathrm{H}_{\mathrm{m}}$ across the mucous net was estimated from the modified Tamada-Fujikawa equation which allows calculation of the pressure drop, $\Delta \mathrm{P}$, due to water flow through a plane, rectangularmesh filter made of cylindrical fibres at a low Reynolds number (Silvester 1983):

$$
\Delta \mathrm{P}=\mu \bar{u} 8 \pi / \mathrm{h}_{\mathrm{e}} \Lambda_{\mathrm{e}}
$$

where $h_{e}=h_{1} h_{2} /\left(h_{1}+h_{2}\right) ; h_{1}=$ width of mesh; $h_{2}=$ length of mesh; $\Lambda_{\mathrm{e}}=1-2 \ln \tau+\tau^{2} / 6 ; \tau=2 \pi \mathrm{a} / \mathrm{h}_{0} ; \mathrm{h}_{0}=$ $\mathrm{h}_{1} \mathrm{~h}_{2} / \sqrt{\mathrm{h}_{1}^{2}+\mathrm{h}_{2}^{2}} ; \mathrm{a}=$ radius of cylindrical fibre; $\mu=$ dynamic viscosity of seawater. The mucous net dimensions used were: $\mathrm{a}=20 \mathrm{~nm} ; \mathrm{h}_{1}=0.35 \mu \mathrm{m} ; \mathrm{h}_{2}=1.35 \mu \mathrm{m}$ (Flood \& Fiala-Médioni 1981). The estimated pressure drop across the filter, $\Delta \mathrm{H}_{\mathrm{m}}$, amounted to $0.069 \mathrm{~mm}$ $\mathrm{H}_{2} \mathrm{O}$.

In Styela \# 12 the inhalant and exhalant siphon apertures were found to be 0.8 and $0.5 \mathrm{~cm}$ respectively. The velocity of the water in the inhalant siphon was $0.76 / \pi 0.4^{2}=1.51 \mathrm{~cm} \mathrm{~s}^{-1}$ and $0.76 / \pi 0.25^{2}=3.87 \mathrm{~cm} \mathrm{~s}^{-1}$ in the exhalant siphon. The kinetic energy loss is given by $v^{2} / 2 g$, where $v$ is the mean velocity of the water current in the siphon opening and $g$ is the acceleration due to gravity (Vogel 1981, p. 42, Jørgensen et al. 1986). The entrance and exit kinetic energy loss amounted to 0.012 and $0.076 \mathrm{~mm} \mathrm{H}_{2} \mathrm{O}$, respectively. Thus, $\Delta \mathrm{H}_{\mathrm{k}}$ was $0.088 \mathrm{~mm} \mathrm{H}_{2} \mathrm{O}$.

Table 1. Styela clava. Linear relation between back pressure, $\Delta \mathrm{H}_{12}$, and pumping rate, $\mathrm{V}$, in ascidians, as described by the equation: $\Delta \mathrm{H}_{12}\left(\mathrm{~mm} \mathrm{H}_{2} \mathrm{O}\right)=a-b \mathrm{~V}\left(\mathrm{ml} \mathrm{s}^{-1}\right) . \Delta \mathrm{H}_{12}^{0}$ : back pressure at zero pumping rate; $r$ : correlation coefficient; $\mathrm{V}^{0}$. pumping

\begin{tabular}{|c|c|c|c|c|c|c|c|c|c|c|c|}
\hline \# & $\begin{array}{l}\text { Total } \\
\text { dry wt } \\
\text { (g) }\end{array}$ & $\begin{array}{l}\text { Soft tissue } \\
\text { dry wt } \\
\text { (g) }\end{array}$ & $\begin{array}{l}a=\Delta \mathrm{H}_{12}^{0} \\
\left(\mathrm{~mm} \mathrm{H}_{2} \mathrm{O}\right)\end{array}$ & $b$ & $r$ & $n$ & $\begin{array}{c}v^{0} \\
\left(\mathrm{ml} \mathrm{s}^{-1}\right)\end{array}$ & $\left(\mu 1 \mathrm{O}_{2} \mathrm{~h}^{-1}\right)$ & $(\mu W)$ & $\begin{array}{c}P_{p} \\
(\mu W)\end{array}$ & $\begin{array}{c}\text { Pump work } \\
\qquad\left(\mathrm{P}_{\mathrm{p}} / \mathrm{R}\right) \\
(\%)\end{array}$ \\
\hline 5 & 0.179 & 0.176 & 1.22 & 3.31 & -0.994 & 6 & 0.37 & 200 & 1067 & 1.1 & 0.10 \\
\hline 7 & 0.652 & 0.122 & 1.25 & 4.39 & -0.951 & 5 & 0.29 & 226 & 1206 & 0.9 & 0.08 \\
\hline 10 & 0.948 & 0.176 & 0.95 & 6.29 & -0.989 & 6 & 0.15 & 253 & 1350 & 0.5 & 0.04 \\
\hline 11 & 0.688 & 0.109 & 0.99 & 3.67 & -0.950 & 10 & 0.27 & 176 & 939 & 0.8 & 0.09 \\
\hline 12 & 0.412 & 0.108 & 1.31 & 1.73 & -0.993 & 11 & 0.76 & 167 & 891 & 2.3 & 0.26 \\
\hline 13 & 0.768 & 0.248 & 1.15 & 1.68 & -0.869 & 6 & 0.68 & 283 & 1510 & 2.1 & 0.14 \\
\hline 14 & 0.625 & 0.151 & 1.02 & 2.62 & -0.969 & 19 & 0.39 & 183 & 976 & 1.2 & 0.12 \\
\hline 15 & 0.674 & 0.117 & 1.13 & 4.04 & -0.979 & 12 & 0.28 & - & - & 0.8 & - \\
\hline 17 & 0.543 & 0.138 & 1.20 & 2.61 & -0.999 & 3 & 0.46 & 277 & 1478 & 1.4 & 0.10 \\
\hline 18 & 0.701 & 0.149 & 1.08 & 5.83 & -0.972 & 6 & 0.17 & 226 & 1206 & 0.5 & 0.04 \\
\hline 19 & 0.955 & 0.198 & 1.10 & 3.29 & -0.992 & 5 & 0.33 & 291 & 1553 & 1.0 & 0.06 \\
\hline
\end{tabular}
rate at zero back pressure; $R$ : metabolic rate; $P_{p}=$ pumping power (operating point assumed to be $0.3 \mathrm{~mm} \mathrm{H}_{2} \mathrm{O}$ ) 
The frictional resistance in the inhalant and exhalant siphons, which were 1.2 and $1.0 \mathrm{~cm}$ long respectively, was calculated by using Poiseuille's equation (Vogel 1981, p. 167, Jørgensen \& Riisgård 1988):

$$
\Delta \mathrm{H}=8 \mathrm{~V} v \mathrm{~L} / \pi r^{4} g
$$

where $\mathrm{V}=$ pumping rate; $v=$ kinematic viscosity; $\mathrm{L}=$ siphon length; $r=$ radius of siphon lumen; $g=$ acceleration due to gravity. The frictional resistances in the inhalant $\left(\Delta \mathrm{H}_{1}\right)$ and exhalant $\left(\Delta \mathrm{H}_{\mathrm{e}}\right)$ siphon were calculated to be 0.010 and $0.056 \mathrm{~mm} \mathrm{H}_{2} \mathrm{O}$, respectively. The Poiseuille's equation gives a fairly good estimate of the pressure drop almost to the very entrance of a pipe. It should be noticed, however, that the gradual development of a parabolic velocity profile in the entrance region of especially the inhalant siphon will lead to a greater pressure drop than predicted by the Poiseuille's equation because the kinetic energy of the water increases until the flow is completely controlled by frictional effects. The calculated total pressure drop in the siphons (i.e. $0.066 \mathrm{~mm} \mathrm{H}_{2} \mathrm{O}$ ) may therefore be somewhat underestimated. The total head loss along the flow path from entry to exit has until now been estimated to be: $0.069 \Delta \mathrm{H}_{\mathrm{m}}+0.088 \Delta \mathrm{H}_{\mathrm{k}}+0.010 \Delta \mathrm{H}_{\mathrm{r}}+$ $0.056 \Delta \mathrm{H}_{e}=0.223 \mathrm{~mm} \mathrm{H}_{2} \mathrm{O}$. The resistances to flow in other parts of the pump system (i.e. pharynx chamber, pharyngeal stigmata and atrium) are not known. The pressure losses over the pharynx chamber and atrium are presumably insignificant, and it seems reasonable to suggest that the total pressure loss, and thus the operating point, may amount to about $0.3 \mathrm{~mm} \mathrm{H}_{2} \mathrm{O}$ in the unrestricted and optimally working ascidian pump.

When the normal operating point $\left(\mathrm{O}_{\mathrm{p}}\right)$ is known and a linear relation between pump pressure $\left(\Delta H_{p}\right)$ and pumping rate (V) is assumed, the pump characteristic can be determined on the basis of the back pressurepumping rate characteristic, and expressed as: $\Delta \mathrm{H}_{\mathrm{p}}=$ $\Delta \mathrm{H}^{0}-\mathrm{C}_{\mathrm{p}} \mathrm{V}$, where $\Delta \mathrm{H}_{\mathrm{p}}^{0}=\Delta \mathrm{H}_{12}^{0}$ and $\mathrm{C}_{\mathrm{p}}=\left(\Delta \mathrm{H}_{12}^{0}-\mathrm{O}_{\mathrm{p}}\right) /$ $V^{0}$ (Fig. 3). Further, the power output $\left(P_{p}\right)$ from the pump can be calculated as pumping rate times pressure drop $(\Delta \mathrm{P})$ :

$$
\begin{aligned}
& \mathrm{P}_{\mathrm{p}}=\Delta \mathrm{PV}=\rho g \Delta \mathrm{H}_{\mathrm{p}} \mathrm{V} \\
\text { or } & \mathrm{P}_{\mathrm{p}}=\rho g\left(\Delta \mathrm{H}_{\mathrm{p}}^{0}-\mathrm{C}_{\mathrm{p}} \mathrm{V}\right) \mathrm{V}
\end{aligned}
$$

where $\rho=$ density of seawater $\left(1.024 \times 10^{3} \mathrm{~kg} \mathrm{~m}^{-3}\right) ; g$ $=$ acceleration due to gravity $\left(\mathrm{m} \mathrm{s}^{-2}\right)$. The power curve is a parabola (Fig. 3). For the sample case of Styela \# 12 at zero back pressure and $\Delta \mathrm{H}_{\mathrm{p}}^{0}=1.31 \mathrm{~mm} \mathrm{H}_{2} \mathrm{O}$ it is

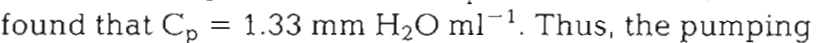
power becomes $\mathrm{P}_{\mathrm{p}}=2.3 \mu \mathrm{W}$. This value may be compared to the maximum value: $P_{p} \cdot \max =3.2 \mu \mathrm{W}$, which applies at $\mathrm{V}=0.49 \mathrm{ml} \mathrm{s}^{-1}$, corresponding to a back pressure of $\Delta \mathrm{H}_{12}=0.46 \mathrm{~mm} \mathrm{H}_{2} \mathrm{O}$.

The work done by the pump may be compared with the total metabolic energy expenditure of the ascidian, as expressed by the rate of oxygen consumption. Styela \# 12 consumed $0.167 \mathrm{ml} \mathrm{O}_{2} \mathrm{~h}^{-1}$ which corresponds to $891 \mu \mathrm{W}$. Thus, the work done by the pump constituted $0.26 \%$ of the total metabolic rate. Other estimated values of work concerned with pumping are shown in Table 1.

\section{DISCUSSION}

The variability of $\mathrm{V}^{0}$ in the present work (Table 1) may partly have been due to different degrees of constriction of the cross-sectional area of the exhalant siphon, exerted by the latex membrane holding the ascidian; but precise and systematic recording of the degree of constriction was not made. The mean value of $V^{0}$ was $0.38 \pm 0.19 \mathrm{ml} \mathrm{s}^{-1}$ for an average-sized individual of $0.154 \pm 0.043 \mathrm{~g}$ (Table 1 ). This value may be compared to filtration rates (= pumping rates) measured by means of an indirect clearance method in undisturbed ascidians Ascidiella aspersa and Ciona intestinalis (Randlov \& Riisgård 1979). From the equations describing filtration rate as a function of soft tissue dry weight it was found that $0.154 \mathrm{~g}$ individuals of A. aspersa and $C$. intestinalis showed filtration rates of 0.43 and $0.29 \mathrm{ml} \mathrm{s}^{-1}$, respectively. The directly measured filtration rates in this study fall between these values, thus indicating that the measurements have been obtained from undisturbed ascidians.

From the relation between filtration rates and energy requirements it is possible to estimate the concentration of food particles that must be present in the water to cover the metabolic energy need of suspension feeding animals (Jørgensen 1955, 1975). The amount of water filtered in relation to minimal energy requirements, as assessed from rates of oxygen consumption, has been found to be about $13 \mathrm{l}$ per ml of oxygen consumed in Ciona intestinalis (Jørgensen 1955). Water processing potentials of more than 15 I of water filtered per ml of oxygen consumed have been found in mussels Mytilus edulis (Riisgård et al. 1980) and other suspension feeding bivalves, copepods and sponges (Jørgensen 1955, 1975). From $V^{0}$ and $R$ given in Table 1 it was found that $V^{0} / R=6.4 \pm 3.9 \mathrm{l}$ pumped per $\mathrm{ml}$ of oxygen consumed. This value is lower than expected, and seems to indicate that the oxygen consumption was overestimated, possibly due to insufficient mixing of the water in the respiration chamber. Therefore, the 'pump work' $\left(\mathrm{P}_{\mathrm{p}} / \mathrm{R}\right.$ in Table 1$)$ may have been underestimated.

The back pressure-pumping rate characteristic in Styela clava (Fig. 2) is linear, as it is in the bivalve Mytilus edulis, but the maximum pressure amounted to only about $1.2 \mathrm{~mm} \mathrm{H}_{2} \mathrm{O}$ (Table 1), compared to about $3.5 \mathrm{~mm} \mathrm{H}_{2} \mathrm{O}$ in the optimally pumping $M$. edulis 
Fig. 3. Styela clava. Pressure head-pumping rate characteristics for back pressure $\left(\Delta \mathrm{H}_{12}\right)$ and pump pressure $\left(\Delta \mathrm{H}_{\mathrm{p}}\right) . \mathrm{P}_{\mathrm{p}}$ : pumping rate-pumping power characteristic of the ascidian pump. $O_{p}$ : normal operating point

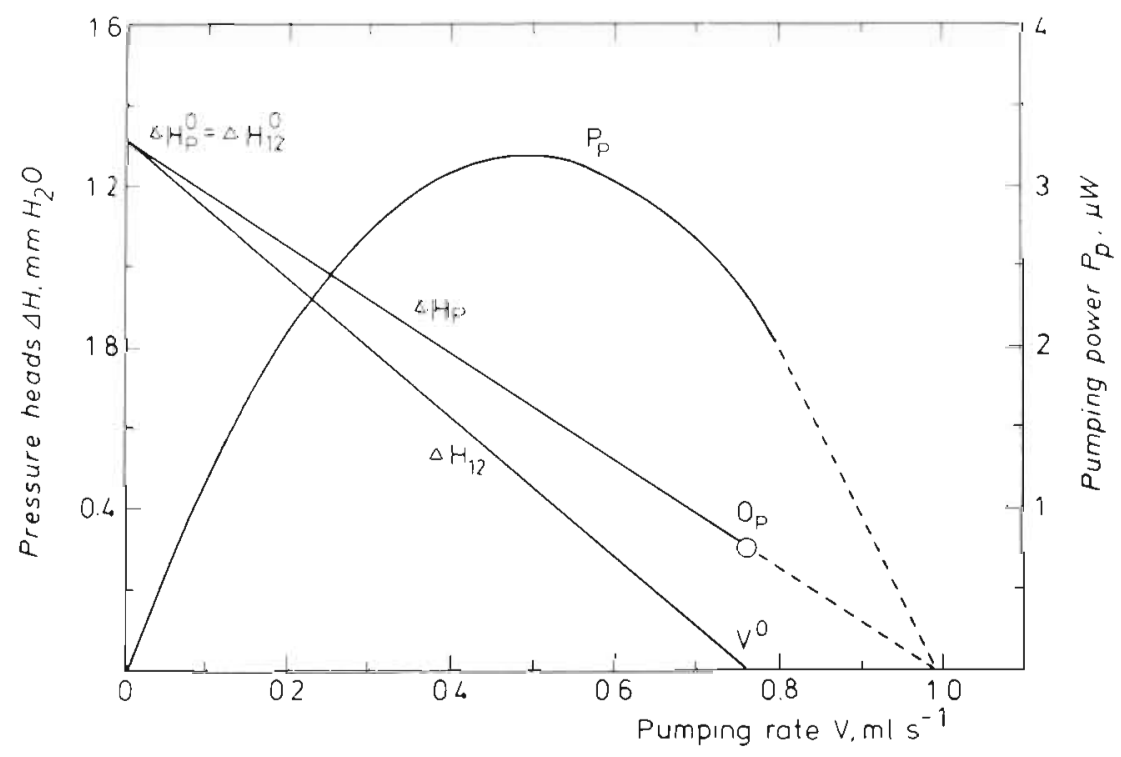

(Jørgensen et al. 1986). The normal operating point in the ascidian pump was found in the present work to be about $0.3 \mathrm{~mm} \mathrm{H}_{2} \mathrm{O}$, or about $25 \%$ of the maximum pressure. In the bivalve gill pump the normal operating point has been found to be about $1 \mathrm{~mm} \mathrm{H}_{2} \mathrm{O}$ or $30 \%$ of the maximum pressure (Jørgensen et al. 1986). The work of the ascidian pump amounted to 0.1 to $0.2 \%$ of the total metabolic energy expenditure (Table 1). This figure may be compared to that found for the bivalve pump where the work constituted 1 to $2 \%$ of the total metabolic expenditure (Jørgensen et al. 1986). The 10 times lower energy cost of the ascidian pump compared to the bivalve pump is a direct consequence of the lower pump pressure in ascidians. Thus, the ascidian pump may be characterized as both a low pressure and a low energy pump compared to the bivalve pump.

It was noted that the maximum pressure rise $\left(\Delta \mathrm{H}_{12}^{0}\right)$ which can be delivered by the ascidian pump is fairly constant and uncorrelated with the pumping rate. In Mytilus edulis maximum pressure and pumping rate decline concurrently with reduced valve gape. This phenomenon is believed to be due to a secondary effect of valve closure which leads to a shortening of the gill axes and thus to reduced distance and subsequent interaction between opposing lateral ciliary bands which reduce the force of the pump (Jørgensen et al. 1988). In Styela clava constriction of the exhalant siphon may reduce the pumping rate, but the force of the pump is not affected because the geometry of the pump (i.e. dimensions of the pharynx stigmata with the water pumping ciliary tracts) is uninfluenced by the local constriction. If, however, the ascidian is disturbed, or if there are no algal cells in the ambient water, the maximum pumping pressure may be reduced (see 'Materials and Methods'), thus indicating reduced activity of the ciliary bands in the stigmata. MacGinitie (1939) observed that only undisturbed ascidians feed normally. Upon 'the least disturbance' the ascidian may cease secretion of the mucous net, and the cilia of the stigmata may stop. Reduced pump force observed in the present work may thus be due to this phenomenon.

Foster-Smith (1976) measured the pressure in the exhalant side of the pharynx of Ciona intestinalis to be 0.11 to $0.15 \mathrm{~mm} \mathrm{H}_{2} \mathrm{O}$, and from a value in the literature for pumping rate he calculated the power needed by this ascidian to sustain its pumping rate to be 0.11 to $0.26 \mu \mathrm{W} \mathrm{g}^{-1}$ soft body wet weight. However, the reliability of the technique used in measuring the pressure (which is not a direct measure of the operating pressure) has recently been questioned (Jørgensen \& Riisgård 1988), and the pumping rate used $\left(0.06 \mathrm{ml} \mathrm{s}^{-1}\right.$ $g$ wet wt) seems to be an underestimate.

Acknowledgements. Thanks are due Drs C. Barker Jørgensen and Michael Depledge for critically reading the manuscript and to $\mathrm{Mr}$ Scott $\mathrm{M}$. Gallager for help and provision of facilities during my stay at the Environmental System Laboratory, Woods Hole. This work was supported by a grant from the Danish Natural Science Research Council (M 11-6385).

\section{LITERATURE CITED}

Famme, P., Riisgård, H. U., Jørgensen, C. B. (1986). On direct measurement of pumping rates in the mussel Mytilus edulis. Mar. Biol. 92: 323-327

Fiala-Médioni, A. (1978). A scanning electron microscope study of the branchial sac of benthic filter-feeding invertebrates (Ascidians). Acta zool., Stockh. 59: 1-9

Flood, P. R., Fiala-Médioni, A. (1981). Ultrastructure and histochemistry of the food trapping mucous film in benthic filter-feeders (Ascidians). Acta zool., Stockh. 62: 53-65

Foster-Smith, R. L. (1976). Pressure generated by the pumping 
mechanisms of some ciliary filter-feeders. J. exp. mar. Biol. Ecol. 25: 199-206

Holley, M. C. (1986). Cell shape, spatial patterns of cilia, and mucus-net construction in the ascidian endostyle. Tissue \& Cell. 18: 667-684

Jørgensen, C. B. (1955). Quantitative aspects of filter feeding in invertebrates. Biol. Rev. 30: 391-454

Jørgensen, C. B. (1975). Comparative physiology of suspension feeding. Ann. Rev. Physiol. 37: 57-79

Jørgensen, C. B., Kiørboe, T., Møhlenberg, F., Riisgård, H. U. (1984). Ciliary and mucus-net filter feeding, with special reference to fluid mechanical characteristics. Mar. Ecol. Prog. Ser. 15: 283-292

Jørgensen, C. B., Famme, P., Saustrup Kristensen, H., Larsen, P. S., Mohlenberg, F., Risgård, H. U. (1986). The bivalve pump. Mar. Ecol. Prog. Ser. 34: 69-77

Jørgensen, C. B., Larsen, P. S., Møhlenberg, F., Risggård, H. U. (1988). The mussel pump: properties and modelling. Mar Ecol. Prog. Ser. 45: 205-216
Jørgensen, C. B., Riisgård, H. U. (1988). Gill pump characteristics of the soft clam Mya arenaria. Mar. Biol. (in press)

MacGinitie, G. E. (1939). The method of feeding of tunicates. Biol. Bull. mar biol. Lab., Woods Hole 77: 443-447

Millar, R. H. (1971). The biology of ascidians. Adv. mar. Biol. 9: $1-100$

Randlov, A., Riisgård, H. U. (1979). Efficiency of particle retention and filtration rate in four species of ascidians. Mar. Ecol. Prog. Ser 1. 55-59

Riisgård, H. U., Randløv, A., Kristensen, P. S. (1980). Rates of water processing, oxygen consumption and efficiency of particle retention in veligers and young post-metamorphic Mytilus edulis. Ophelia 19: $37-47$

Silvester, N. R. (1983). Some hydrodynamic aspects of filter feeding with rectangular-mesh nets. J. theor. Biol. 103: 265-286

Vogel, S. (1981). Life in moving fluids. The physical biology of flow. Princeton University Press, New Jersey

This article was submitted to the editor; it was accepted for printing on June 3, 1988 